\title{
Helpfull hints for writing SI units
}

To the Editor: We often read medical writing, e.g. assignments, dissertations and manuscripts, where the International System of Units (SI) is not used optimally. The abbreviation 'SI' is derived from Le Système International d'Unités, which refers back to the Metre Convention of 1875 in Paris. We want to share four hints that have helped us.

The best resource for SI units is the latest edition of the SI Brochure of the International Bureau of Weights and Measures (BIPM) ${ }^{[1]}$ South Africa is a full member state of the BIPM. The Author Guidelines of the $S A M J^{[2]}$ in fact follow the SI Brochure.

Always insert a space between the numeral and the unit. The SI units of measurement are treated as mathematical entities (e.g. ' $3.5 \mathrm{~kg}$ ' and not ' $3.5 \mathrm{~kg}$ '). The value of a quantity is the product of the numerical value multiplied by the unit. ${ }^{[3]}$ One of the exceptions is that degrees Celsius $\left({ }^{\circ} \mathrm{C}\right)$ are written without the space between the numeral and unit (e.g. $\left.5^{\circ} \mathrm{C}\right)$. To prevent the unit wrapping to the next line and losing contact with the numeral, use a 'hard space' that does not break (Ctrl + Shift + Space in Microsoft Word).$^{[4]}$

The litre can be abbreviated as 'l' or 'L', and 'millilitre' as ' $\mathrm{ml}$ ' or ' $\mathrm{mL}$ '. The symbol for litre was designated ' 1 ' in $1879 .{ }^{[5]}$ Some countries were afraid that 'l' might be confused with ' 1 ', and therefore changed the 'l' to ' $\mathrm{L}$ ' [SAMJ has recently changed to 'L' - Editor]. The litre is not a base unit of the SI system any longer. It is defined as a cubic decimetre. ${ }^{[6]}$

Numbers with many digits can be divided into groups of three by a space. ${ }^{[7]}$ Do not use commas. When numbers are in a table, the format of the numbers in a column must remain constant.

\section{Marius Coetzee}

Department of Haematology and Cell Biology, University of the Free State and National Health Laboratory Service, Bloemfontein, South Africa coetzeemj@ufs.ac.za

\section{Jaco Joubert}

Department of Haematology and Cell Biology, University of the Free State and National Health Laboratory Service, Bloemfontein, South Africa

\footnotetext{
1. BIPM. The SI Brochure: The International System of Units (SI). 8th ed. Paris: Bureau International des Poids et Mesures (BIPM), 2014:1-180. http://www.bipm.org/en/publications/si-brochure/ (accessed 29 December 2014).

2. Health and Medical Publishing Group. Author Guidelines, South African Medical Journal, 2014. http:// www.samj.org.za/index.php/samj/about/submissions\#authorGuidelines (accessed 29 December 2014). 3. BIPM. Formatting the value of a quantity. In: BIPM: The SI Brochure: The International System of Units (SI). 8th ed. Paris: Bureau Internation des Poids et Mesures (BIPM), 2014:133. http.//www. bipm.org/en/publications/si-brochure/ (accessed 29 December 2014).

4. Brownridge D. A Practical Guide to the International System of Units. Colorado State University: US Metric 4. Brownridge D. A Practical Guide to the International System of Units. Colorado State University: US Me 5. Resolution 6 of the 16th CGPM: Symbols for the Litre 1979. Paris: Bureau International des Poids et 5. Resolution 6 of the 16th CGPM: Symbols for the Litre 1979. Paris: Bureau International
Mesures (BIPM). http://www.bipm.org/en/CGPM/db/16/6/ (accessed 29 December 2014)

6. BIPM. Non-SI units accepted for use with the SI, and units based on fundamental constants. In: BIPM: The SI Brochure: The International System of Units (SI). 8th ed. Paris: Bureau International des Poids et Mesure (BIPM), 2014:123-129. http://www.bipm.org/en/publications/si-brochure/ (accessed 29 December 2014).

7. BIPM. Formatting numbers, and the decimal marker. In: BIPM: The SI Brochure: The International System of Units (SI). 8th ed. Paris: Bureau International des Poids et Mesures (BIPM), 2014:133. http:// www.bipm.org/en/publications/si-brochure/ (accessed 29 December 2014).
}

S Afr Med J 2015;105(2):80. DOI:10.7196/SAMJ.9337 